\title{
Pelatihan Pengembangan Perangkat Pembelajaran di SMP Setia Negara
}

\author{
Syarifuddin* \\ Fakultas Keguruan dan Ilmu Pendidkan, Universitas Ibn Khaldun, Bogor, Indonesia \\ *Coresponding Author: syarifuddin@uika-bogor.ac.id \\ Dikirim: 10-01-2022; Direvisi: 12-01-2022; Diterima: 13-01-2022
}

\begin{abstract}
Abstrak: Salah satu tri darma perguruan tinggi yang harus rutin dilaksanakan oleh semua tenaga pendidik (dosen) adalah melaksanakan pengabdian masyarakat secara rutin dan terjadwal dalam setiap tahunnya. Salah satu program pelaksanaan tri darma tersebut adalah melaksanakan pelatihan pengembangan perangkat pembelajaran yang melibatkan sekolah SMP Setia Negara di Pancoran Mas Kota Depok Jawa Barat sebagai bentuk kemitraan strategis perguruan tinggi dan satuan pendidikan lain dalam meningkatkan mutu pendidikan. Pelaksanaan pelatihan pengembangan perangkat pembelajaran merupakan salah satu langkah desain pembelajaran yang efektif dan efisien dengan capaian yang akan diraih belajar sukses. Hasil dari kegiatan ini yaitu menghasilkan perangkat pembelajaran dan mendorong guru untuk dapat mengembangkan perangkat pembelajaran dengan menggunakan berbagai model pengembangan perangkat pembelajaran dalam berbagai pendekatan sesuai kebutuhan serta gaya belajar anak.
\end{abstract}

Kata Kunci: Pengembangan perangkat pembelajaran; Pembelajaran efektif

\begin{abstract}
One of the three dharmas of higher education that must be routinely carried out by all educators (lecturers) is to carry out community service regularly and scheduled every year. One of the programs to implement the tri dharma is to carry out training on the development of learning tools involving the Setia Negara Junior High School in Pancoran Mas, Depok City, West Java as a form of strategic partnership between universities and other educational units in improving the quality of education. The implementation of training in the development of learning tools is one of the steps in effective and efficient learning design with the achievements of successful learning. The results of this activity are to produce learning tools and encourage teachers to be able to develop learning tools by using various models of developing learning tools with approaches according to the needs and learning styles of children.
\end{abstract}

Keywords: Development of learning tools; Effective learning

\section{PENDAHULUAN}

Tuntutan menghasilkan proses pembelajaran pembelajaran yang efektif dan efisien sangat diharapkan tercapai pada pelaksanaan proses pembelajaran oleh semua tenaga guru sebagai pelaksana transformasi ilmu pengetahuan dikelas bahkan lingkungan pendidikan pada umumnya. Oleh Karen itu, dalam proses mencapai tujuan pembelajaran yang efektif dan efisien, maka sangat diperlukan perangkat pembelajaran yang didasarkan pada kebutuhan dan kondisi lingkungan pembelajaran yang ada saat ini dan dimasa yang akan datang. Perangkat pembelajaran merupakan segala alat dan bahan yang digunakan guru untuk melaksanakan proses pembelajaran (Widodo dkk, 2018; Syarifuddin dkk, 2021). Lebih lanjut perangkat pembelajaran merupakan hal yang harus disiapkan oleh guru sebelum melaksanakan pembelajaran, perangkat pembelajaran juga adalah alat atau perlengkapan untuk melaksanakan 
proses yang memungkinkan pendidik dan peserta didik melakukan kegiatan pembelajaran.

Perangkat pembelajaran juga perlu perencanaan yang terencana dengan baik, baik itu yang berupa perencanaan proses pembelajaran maupun materi serta alat evaluasinya, memungkinkan pembelajaran yang dilakukan dapat berjalan optimal sesuai yang diharapkan. Perangkat pembelajaran selanjutnya dapat membantu proses pembelajaran untuk mencapai tujuan yang sudah ditentukan. Perangkat pembelajaran dalam mengelola proses belajar berupa: Silabus, Rencana pelaksanaan pembelajaran, Buku ajar siswa, Lembar kegiatan siswa, tes hasil belajar dan media pembelajaran (Ahmad et al., 2019; Purnamasari \& Wangid, 2016). Lebih lanjut dijelaskan bahwa perangkat pembelajaran yang harus memperhatikan pengembangan kompetensi yang harus dimiliki oleh siswa setelah mengikuti proses pembelajaran, perangkat pembelajaran juga harus mampu mengintegrasikan kemampuan pengetahuan, sikap dan nilai yang akan dimiliki oleh siswa serta keterampilan hidup yang akan menjadi bekal hidup pada eranya. Oleh karena itu, perangkat pembelajaran yang dapat mengantarkan siswa menjadi pembelajar yang kompeten. Maka perlu dikembangkan model perangkat pembelajaran yang sesuai dengan model pembelajaran yang mengembangkan gaya serta minat belajar siswa pada situasi apapun dan dimanapun siswa akan melaksanakan proses pembelajaran berlansung (Amir dkk, 2015; Fahrurrozi \& Mohzana, 2020).

Pengabdian masyarakat yang dilaksanakan ini berupaya lewat pelatihan pengembangan perangkat pembelajaran yang sesuai dengan kebutuhan dan situasi yang dihadapi oleh sekolah dalam pelaksanaan proses pembelajaran di sekolah maupun yang diberikan pada siswa untuk belajar di rumah.

\section{METODE PELAKSANAAN KEGIATAN}

Metode yang digunakan dalam kegiatan pengabdian masyarakat ini ialah dengan metode ceramah dan diskusi yang diselenggarakan dalam bentuk group diskusi terfokus terkait model pengembangan perangkat pembelajaran yang sering dihadapi oleh sekolah dan guru dalam melaksanakan proses pendidikan selama ini. Pelaksanaan pengabdian masyarakat yang dilaksanakan dalam bentuk pelatihan berupa pemaparan materi serta masalah yang sering dihadapi oleh sekolah dan guru selama melaksanakan proses pembelajaran di sekolah.

Adapaun materi yang disampaikan dalam kegiatan pelatihan pengembangan perangkat pembelajaran di SMP Setia Negara di Pancoran Mas Kota Depok Jawa Barat sebagai mitra pengabdian masyarakat adalah: Model-model dan bentuk pengembangan perangkat pembelajaran serta kiat mengembangkan perangkat pembelajaran yang efektif dan efisien serta sukses. Sasaran kegiatan pengabdian masyarakat yang dilaksanakan adalah guru mata pelajaran dan tim penjaminan mutu sekolah serta tim pengembang kurikulum.

\section{IMPLEMENTASI KEGIATAN DAN PEMBAHASAN}

Hasil dan luaran kegiatan pada pemaparan materi pertama tentang Modelmodel pengembangan perangkat pembelajaran oleh Syarifuddin, S. Pd., M. Pd. Diuraikan sebagaimana berikut ini: 
a. Tahap awal yang dilakukan oleh pemateri adalah mengidentifikasi masalahmasalah yang biasa dihadapi oleh sekolah, guru dan tim pengembang kurikulum dengan menggali informasi yang mendalam terkait fokus masalah serta respon sekolah dan guru dalam menghadapi masalah pembelajaran yang ada di sekolah. Hasil yang didapatkan adalah inventarisasi masalah yang muncul dapat dilakukan dengan memberikan kesempatan pada pihak sekolah dan guru dalam menyampaikan informasi awal yang sering dihadapi selama ini, sehingga pemateri dapat memetakan masalah awal yang sering dihadapi oleh pihak sekolah mitra yang ada dalam forum diskusi terfokus tersebut.

b. Pada tahap kedua, pemateri memaparkan masalah-masalah yang ada dalam proses pengembangan perangkat pembelajaran oleh sekolah, guru dan tim pengembang kurikulum yang ada. Pemateri menyampaikan langkah-langkah normative yang dapat dilakukan dalam menyelesaikan masalah yang sering muncul saat menghadapi persiapan pembelajajran dan bahkan dalam proses pelaksanaan pembelajaran yang berlangsung di dalam kelas bahkan di rumah oleh anak.

c. Tahap ketiga dan selanjutnya pemateri memberikan kesempatan pada para peserta untuk memberikan tanggapan terhadap paparan masalah yang diberikan dan mendiskusikan secara serius langkah pemecahan masalah yang sering timbul tersebut. perubahan kurikulum yang terus menyesuaikan dengan tuntutan pembelajaran serta tantangan yang dihadapi oleh bangsa menjadi salah satu sumber utama masalah kesulitan menyesuaikan cara pengembangan perangkat pembelajaran yang sesuai serta kebutuhan belajar siswa yang cenderung sering berubah menjadi salah tantangan juga bagi tenaga guru saat ini. Oleh Karen itu, berangkat dari persoalan yang disampaikan oleh guru-guru dalam kegiatan pelatihan tersebut pemateri melanjutkan paparan materi tentang: Model-model dan bentuk pengembangan perangkat pembelajaran serta kiat mengembangkan perangkat pembelajaran yang efektif dan efisien serta sukses. Menjawab kerisauan kalangan guru sekolah mitra pelaksanaan kegiatan pengabdian masyarakat yang kami lakukan setiap tahunnya.

Pada hasil dan luaran kegiatan pelatihan pengembangan perangkat pembelajaran pada tahap akhir, akan diuraikan sebagai berikut:

1) Kelompok guru mata pelajaran yang terdiri dari: guru mata pelajaran Pendidikan agama dan budi pekerti, matematika, bahasa Indonesia, PPKn, IPA, IPS, Bahasa Inggris dan PJOK. Guru-guru tersebut menyiapkan daftar kompetensi inti untuk dianalisis sesuai tahapan dan tingkatan kompetensi yang akan diajarkan pada siswa.

2) Guru dari masing-masing mata pelajaran menghasilkan daftar analisis kompetensi yang akan menjadi atau dituangkan dalam daftar kompetensi inti pembelajaran.

3) Hasil analisis kompetensi inti kemudian menjadi rujukan dalam menentukan kompetensi dasar dan indikator pencapaian kompetensi pembelajaran yang akan dicapai pada setiap pelaksanaan pembelajaran dikelas.

4) Penentukan kompetensi dasar dan indikator pencapaian kompetensi akan dijadian rujukan utama dalam penentuan tujuan pembelajaran yang kemudian dijadikan dasar dalam menyiapkan materi pembelajaran oleh guru dan siswa. 
5) Penyusunan materi pembelajaran yang didasarkan pada tujuan pembelajaran, kemudian langkah pemilihan pendekatan, model, metode dan media pembelajaran yang sesuai dengan karakter pembelajaran serta alokasi waktu pelaksanaan pembelajaran yang sudah ditentukan.

6) Rumusan tujuan pembelajaran juga diarahkan untuk dijadikan rujukan utama dalam menyiapkan alat evaluasi/penilaian proses serta hasil pembelajaran.

7) Pada alat evaluasi/penilaian proses pembelajaran, memuat beberapa bentuk penilaian diantaranya: Penilaian pengetahuan, penilaian sikap dan penilaian pada aspek keterampilan yang ditunjukkan oleh siswa pada akhir pelaksanakan pembelajaran. alat penilaian hasil pembelajaran dapat berbentuk alat tes tulis yang dapat diberikan secara individu maupun kelompok pada siswa dengan dasar pada tujuan dan materi pembelajaran. setelah beberapa tahap pengembangan perangkat pembelajaran yang telah dilalui oleh semua guru yang ikut dalam kegiatan pelatihan tersebut. Langkah selanjutnya adalah pemeriksaan hasil penyusunan perangkat pembelajaran oleh pemateri yang kemudian divalidasi oleh tim penjamin mutu dan pimpinan sekolah sebagai bentuk luaran hasil kegiatan pelatihan yang telah dilaksanakan.

Demikian beberapa langkah proses pelatihan yang telah dilaksanakan dalam bentuk pelatihan/semi lokakarya pengembangan perangkat pembelajaran. Begitu banyak manfaat yang didapatkan oleh pihak sekolah, guru dalam kegiatan pelatihan pengembangan perangkat pembelajaran serta tim pengembang kurikulum sebagai bagian dari penjaminan mutu pembelajaran disekolah karena dapat melaksanakan proses penyiapan perangkat pembelajaran yang efektif, efisien dan sukses. Oleh karena itu pemateri dalam menyampaikan hal-hal di atas dengan menggunakan pendekatan yang sama dengan pelaksanaan penyampaian serta pembahasan materi pertama di atas, sehingga target yang diharapkan dapat tercapai secara efektif dan efisien dalam pelaksanaan program pengabdian masyarakat yang dilaksanakan secara individu dengan sekolah mitra dan staeholders yang ada.

Kemudian selanjutnya lebih jauh ditambahkan pada aspek kesesuaian dengan tujuan pembelajaran, memiliki rumusan tujuan yang baik. Penulisan tujuan pembelajaran agar mengikuti format ABCD yaitu: Audience, Behavior, Condition dan Degree. Penentuan kompetensi dasar dan standar kompetensi serta indikator perlu memperhatikan kesesuaian berdasarkan pada analisis kompetensi, penentuan kompetensi inti, kompetensi dasar dan Indikator pembelajaran yang telah disusun. Hasil analisis dokumen yang dilakukan oleh peneliti sejalan dengan hasil wawancara dengan pimpinan sekolah dan guru yang melaksanakan penyusunan penulisan tujuan pembelajaran mengacu pada ketentuan Permendikbud No. 22 Tahun 2016 tentang Standar Proses Pendidikan Dasar dan Menengah bahwa tujuan pembelajaran dirumuskan berdasarkan analisis kompetensi, kompetensi inti, kopetensi dasar dan indikator pembelajaran dengan menggunakan kata kerja operasional yang dapat diamati dan diukur, cakupan dalam merumusannya meliputi sikap, pengetahuan, dan keterampilan serta kesesuaiannya dengan rumus ABCD. Pada konteks pembelajaran, desain instruksional dapat diartikan sebagai proses yang sistematis untuk memecahkan persoalan pembelajaran melalui proses perencanaan bahan-bahan pembelajaran beserta aktivitas yang harus dilakukan, perencanaan sumber-sumber pembelajaran yang dapat digunakan serta perencanaan evaluasi keberhasilan. Dengan kata lain, desain insruksional membantu para guru dan desain instruksional 
menciptakan atau merancang pembelajaran yang sesuai dengan tujuan instruksional, yang efektif dan efisien. Sehingga dalam prosesnya akan tercipta proses komunikasi dan pembelajaran yang aktif dan interaktif di antara guru dan siswa (Sanjaya, 2015: 66).

Tujuan Instruksional Khusus atau yang disingkat dengan TIK merupakan terjemahan dari specific instructional objective yang di dalam literatur asing disebut sebagai objective atau enabling objective, untuk membedakannya antara general instructional objective, goal, atau terminal objective yang berarti tujuan instruksional umum (TIU) atau tujuan instruksional akhir (Suparman, 2014). Tujuan instruksional yang sudah sangat rinci, sasaran belajar harus dituliskan dari segi kemampuan peserta didik. Artinya mengungkapkan perubahan apa yang diharapkan terjadi pada diri mahasiswa setelah mengikuti pengajaran pada satu pokok bahasan tertentu, Soekartawi dkk (1995: 41). Dick dan Carey (Suparman, 2014:213) telah mengulas perumusan tujuan instruksional yang khusus dengan sebuah kalimat yang jelas dapat diukur. Perumusan tersebut berarti tujuan instruksional khusus diungkapkan dengan tertulis dan di informasikan kepada peserta didik atau mahasiswa serta guru (pengajar) mempunyai pengertian yang sama tentang apa yang tercantum dalam tujuan instruksional khusus. Perumusan tujuan instruksional khusus dilakukan secara pasti dengan pengertian yang tercantum dalamnya hanya mengandung satu dan tidak dapat ditafsirkan kepada bentuk lain. Untuk itu tujuan instruksional khusus harus dirumuskan dalam kata kerja yang dapat dilihat oleh mata (Suparman, 2014:213). Penulisan sasaran belajar sedikitnya menyatakan tentang: a). Isi materi dan bahasan b). Tingkat penampilan yang diharapkan c). Prasyarat pengungkapan hasil kerja. Tentunya secara ideal diharapkan peserta didik mendapatkan perubahan secara menyeluruh, baik dalam pengetahuan (kognitif), sikap (afektif), maupun keterampilan (motorik) (Soedjarwo, 1995: 81; Magdalena dkk, 2021).

Berdasarkan tinjauan konseptual dari beberapa ahli desain pembelajaran di atas, menjadi rujukan akademik bagi setiap pengembangan perangkat pembelajaran dalam menghasilkan proses pembelajaran yang efektif, efisien dan sukses bagi setiap jenjang pembelajaran yang dilakukan oleh siswa dan guru dalam berbagai situasi.

\section{KESIMPULAN}

Berdasarkan seluruh rangkaian kegiatan pelatihan pengembangan perangkat pembelajaran di SMP Setia Negara di Pancoran Mas Kota Depok Jawa Barat dapat diambil kesimpulan bahwa pelatihan pengembangan perangkat pembelajaran untuk setiap tingkatan sekolah pada jenjang pendidikan formal sangat perlu dilaksanakan secara periodik. Selama kegiatan dilaksanakan sangat memberikan stimulus pengetahuan kepada guru-guru sebagai pelaksanakan pembelajaran, dapat juga memberikan motivasi ekstrinsik dalam menyiapkan semua perangkat pembelajaran yang diperlukan selama mengemban tugas mendidik pada masing-masing mata pelajaran yang diampuh.

Perangkat pembalajran merupakan bagian yang integral dalam pelaksanaan pembelajaran yang efektif, efisien dan sukses karena perangkat pembelajaran dapat memberikan acuan normative dan mengarahkan bagi guru saat melaksanakan pembelajaran disekolah bahkan saat memberikan tugas secara individu kepada siswa serta akan dijadikan acuan dalam menilai kesuksesan proses pembelajaran yang dilaksanakan oleh guru dan siswa. 


\section{DAFTAR PUSTAKA}

Ahmad, Mataram, K., Model, R., Skills, C., \& Karakter, P. P. (2019). Century Skills . Hal ini mengacu pada Standar Kompetensi Lulusan (SKL) yang tercermin pada Permendikbud No. 54 Tahun 2013. Penerapan kurikulum 13 yang mengacu. Jurnal Pendidikan Dan Pengabdian Masyarakat Vol. 2 No. 3, Agustus 2019, 2(3), 343-347.

Amir, M., Muris, M., \& Arsyad, M. (2015). Pengembangan Perangkat Pembelajaran Berbasis Pengalaman Pada Peserta Didik Kelas XI IPA SMA Negeri 9 Pinrang. Jurnal Sains dan Pendidikan Fisika, 11(3), 202-213.

Fahrurrozi, M., \& Mohzana, Z. (2020). Pengembangan Perangkat Pembelajaran Tinjauan Teoretis dan Praktik. Selong: Universitas Hamzanwadi Press

Magdalena, I., Yuniawan, N., Oktania, A., \& Fauzi, H. N. (2021). Tujuan Intruksional Khusus (TIK) dalam Proses Pembelajaran di SD Negeri Tigaraksa IV. EDISI: Jurnal Edukasi dan Sains, 3(3), 417-433.

Purnamasari, V., \& Wangid, M. N. (2016). Pengembangan Perangkat Pembelajaran Berbasis Scientific Approach Untuk Membangun Karakter Kepedulian Dan Kedisiplinan. Jurnal Pendidikan Karakter, 6(2).

Sanjaya, W. (2009). Kurikulum dan Pembelajaran, Jakarta: Kencana.

Soekartawi, Suhardjono,Hartono dan Ansharullah. (1995). Meningkatkan Rancangan Instruksional untuk Memperbaiki Kualitas Belajar Mengajar. Jakarta: PT. Raja Grafindo Persada.

Suparman, A. (2014). Desain Instruksional Modern, Jakarta: Kencana

Syarifuddin, S., Basri, H., Ilham, M., \& Fauziah, A. F. (2021). Efektifitas Pembelajaran Daring Mahasiswa Pendidikan Matematika ditengah Pandemi Covid-19. JagoMIPA: Jurnal Pendidikan Matematika dan IPA, 1(1), 1-8.

Widodo, W., Rahmawati, L., Indratno, T. K., \& Puspita, A. D. (2018). Pelatihan Pengembangan Perangkat Pembelajaran Fisika Berbasis Keterampilan Proses di SMP Muhammadiyah 2 Depok Sleman. Jurnal Pemberdayaan: Publikasi Hasil Pengabdian Kepada Masyarakat, 4 1(2), 447. https://doi.org/10.12928/jp.v1i2.364 